\title{
Faculty of Medicine, Siriraj Hospital, Mahidol University, Bangkok, Thailand*
}

Siriraj Hospital and its medical school constitute the oldest medical institute in Thailand, founded in 1888 and 1889 respectively by the Royal command and Patronage of King Chulalongkorn (Rama V), whose wisdom and effort had led his country toward Western civilization. A hospital was built on selected ground on the west bank of Chao Phraya River opposite the Royal Palace. The wooden structured hospital was declared open to the public in 1888 .

A period of reorganization to attain international standards began in 1923. The medical curriculum was maintained with periodic slight modifications to conform with the contemporary progress of medical sciences in the Western World, and the School was transferred to the University of Medical Sciences in 1943 under the Ministry of Health.

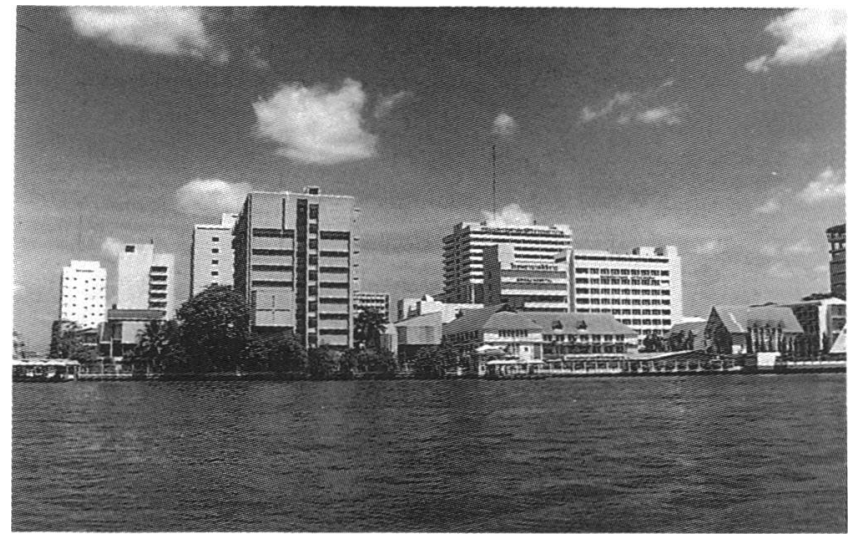

Figure 1. Siriraj Hospital

Table 1. Siriraj Hospital: teaching staff

\begin{tabular}{|c|c|c|c|c|c|}
\hline Department & Professors & Associate Professors & Assistant Professors & Instructors & Total \\
\hline \multicolumn{6}{|l|}{ Preclinical } \\
\hline & - & 4 & 18 & 12 & 34 \\
\hline Biochemistry & - & 3 & 5 & 8 & 16 \\
\hline $\begin{array}{l}\text { Clinical Pathology } \\
\text { Physiology }\end{array}$ & 1 & 2 & 3 & 4 & 10 \\
\hline $\begin{array}{l}\text { Physiology } \\
\text { Pharmacology }\end{array}$ & 2 & 5 & 2 & 9 & 18 \\
\hline Pharmacology & 1 & 4 & 3 & 7 & 15 \\
\hline Microbiology & 2 & 9 & 5 & 6 & 22 \\
\hline Parasitology & 1 & 4 & 1 & 3 & 9 \\
\hline Pathology & 3 & 9 & 7 & 5 & 24 \\
\hline \multicolumn{6}{|l|}{ Clinical } \\
\hline Medicine & 16 & 29 & 12 & 9 & 66 \\
\hline Surgery & 7 & 21 & 22 & 10 & 60 \\
\hline Obstetrics and Gynaecology & 6 & 22 & 18 & 2 & 48 \\
\hline Radiology & 5 & 25 & 12 & 12 & 54 \\
\hline Paediatrics & 4 & 13 & 16 & 4 & 37 \\
\hline Orthopaedic Surgery & 1 & 16 & 8 & 28 & 53 \\
\hline Ophthalmology & 1 & 5 & 10 & 4 & 20 \\
\hline Otorhinolaryngology & - & 2 & 10 & 5 & 17 \\
\hline Anaesthesiology & 3 & 12 & 23 & 8 & 46 \\
\hline Forensic Medicine & 2 & 8 & 3 & 1 & 14 \\
\hline Preventive and Social Medicine & 2 & 5 & 6 & 1 & 14 \\
\hline Psychiatry & 2 & 2 & 3 & 6 & 13 \\
\hline Transfusion Medicine & 1 & - & - & 2 & 3 \\
\hline Cardiac Centre & 1 & - & - & - & 1 \\
\hline Total & & & & & 594 \\
\hline
\end{tabular}
*From information kindly supplied by Dr Kulthanan, Department of Orthopaedic Surgery, Faculty of Medicine, Siriraj Hospital, Mahidol
University, Bangkok, Thailand

(C) 1993 Butterworth-Heinemann Ltd 0306-3674/93/020085-03 
Table 2. Siriraj Hospital: total staff

\begin{tabular}{lr}
\hline & $\begin{array}{c}\text { Approximate } \\
\text { number }\end{array}$ \\
Physicians - all are teaching staff of the related & 578 \\
$\quad$ clinical departments & 397 \\
Residents & 39 \\
Pharmacists & 1782 \\
Graduate nurses & 26 \\
Dieticians & 10 \\
Dentists & 1268 \\
Practical nurses & 25 \\
Social workers & 13 \\
Physical therapists & 32 \\
Medical technologists & 1854 \\
Permanent employees & 1065 \\
Temporary employees, e.g. clerks, typists, maids & \\
$\quad$ etc. & 7089 \\
Approximate total & \\
\hline
\end{tabular}

Other paramedical and vocational programmes have been established to fulfil the needs of provincial hospitals, universities and the Faculty of Medicine including Siriraj Hospital. The teaching courses run in each speciality are under the supervision of the department concerned, which include:

1. the School of Practical Nursing, founded in 1959, under the organization of Siriraj Hospital

2. the School of Physiotherapy, founded in 1965, under the Department of Orthopaedic Surgery

3. the School of Medical Illustration and Audiovisual Technology, founded in 1966, and part of the Dean's Office

4. the School of Medical Technicians, founded in 1967, within the Department of Physiology

5. the School for Nurse Anaesthetists, founded in 1970, within the Department of Anaesthesiology

6. the School for Medical Technicians (Radiological Technology), founded in 1980, within the Department of Radiology

7. the School of Sports Medicine, founded in 1987, within the Department of Orthopaedic Surgery.

The total number of staff is 595, all being full-time as detailed in Tables 1-4.

The number of research projects during a 3-year period rose from 185 in 1988 to 212 in 1990 . Of these, approximately $75 \%$ were clinically orientated research. In 1989, there were 280 publications appearing in international peer-review journals.
Table 3. Siriraj Hospital: total outpatients and inpatients, 1990

\begin{tabular}{|c|c|c|c|c|}
\hline \multirow[t]{2}{*}{$\begin{array}{l}\text { Department or } \\
\text { Division }\end{array}$} & \multicolumn{2}{|c|}{$\begin{array}{l}\text { Number of } \\
\text { outpatients }\end{array}$} & \multicolumn{2}{|c|}{$\begin{array}{l}\text { Number of } \\
\text { inpatients }\end{array}$} \\
\hline & peryear & perday & peryear & perday \\
\hline Medicine & 337390 & 924 & 8649 & 24 \\
\hline Dermatology & 49548 & 136 & $*$ & - \\
\hline Surgery & 109662 & 300 & 7744 & 21 \\
\hline Orthopaedics & 47220 & 129 & 1136 & 3 \\
\hline Obstetrics & 110564 & 303 & 21672 & 59 \\
\hline Gynaecology & 114160 & 313 & 3712 & 10 \\
\hline Paediatrics & 110267 & 302 & 5220 & 14 \\
\hline Ophthalmology & 62175 & 170 & 2687 & 7 \\
\hline Otorhinolaryngology & 62685 & 172 & 1636 & 5 \\
\hline Psychiatry & 17750 & 49 & 217 & 1 \\
\hline Radiology & - & - & 871 & 2 \\
\hline Dentistry & 33130 & 91 & - & - \\
\hline Total & 1054551 & 2889 & 53544 & 146 \\
\hline Casualty & 72718 & 199 & $t$ & - \\
\hline Total & 1127269 & 3088 & 53544 & 146 \\
\hline
\end{tabular}

*Included in Medicine

tIncluded in Surgery and Orthopaedics depending on type of injuries

Table 4. Siriraj Hospital: numbers of beds available for admissions, 1990

\begin{tabular}{lccr}
\hline Department & \multicolumn{3}{c}{ Available beds } \\
\cline { 2 - 4 } & Common & Private & Total \\
\cline { 2 - 4 } & 227 & 45 & 272 \\
Medicine & 301 & 38 & 339 \\
Surgery & 76 & 11 & 87 \\
Orthopaedics & 276 & 69 & 345 \\
Obstetrics & 97 & 21 & 118 \\
Gynaecology & 329 & 22 & 351 \\
Paediatrics & 86 & 20 & 106 \\
Ophthalmology & 80 & 19 & 99 \\
Otorhinolaryngology & 20 & - & 20 \\
Psychiatry & 25 & 23 & 48 \\
Radiology & - & 220 & 220 \\
Unspecified & 1517 & 488 & 2005 \\
Total & 261 & 66 & 327 \\
Bassinets & 1778 & 554 & 2332 \\
Grand total & & & \\
\hline
\end{tabular}

